\title{
Features of disciplinary liability of police officers
}

\section{Особенности дисциплинарной ответственности работников полиции}

Received: April 25, 2021

\begin{abstract}
The objective of this article is to formulate the definition of the notion of disciplinary responsibility of police officers, to highlight and study the features of this legal phenomenon in the legal system of individual European states. The research was carried out on a complex of general and special scientific methods. In particular, was used the hermeneutic, the logical method of convergence from simple to complex, the logical-semantic, the logical-legal, the comparative-legal method. The author of this article has studied the features of the disciplinary responsibility of police officers. The author focuses on the fact that the disciplinary responsibility of police officers has a number of features: 1) police officers are subjects of special disciplinary responsibility; 2) the content of a disciplinary offense (misconduct) of a police officer is broader than that of persons who are not in the public service; 3) the number of disciplinary sanctions applied to police officers is wider than for employees who are not in the public service; 4) the procedure for bringing to disciplinary responsibility of police officers of Ukraine is specific; 5) employees of the National Police of Ukraine are brought to disciplinary responsibility in case of committing any offense (criminal, administrative, civil).
\end{abstract}

Accepted: June 2, 2021

\author{
Written by: \\ Lidija Kalenichenko ${ }^{34}$ \\ https://orcid.org/0000-0003-4068-4729 \\ Dmytro Slynko ${ }^{35}$ \\ https://orcid.org/0000-0001-7960-615X \\ Andrii Sobakar ${ }^{36}$ \\ https://orcid.org/0000-0002-7618-0031 \\ Valentyna Goncharuk ${ }^{37}$ \\ https://orcid.org/0000-0002-8157-0130
}

\footnotetext{
${ }^{34}$ Doctor of Juridical Sciences, Professor, Professor of Department Theory and History of State and Law of the Faculty No. 1 of Kharkiv National University of Internal Affairs, Ukraine.

${ }^{35}$ Doctor of Juridical Sciences, Professor, Professor of Department Theory and History of State and Law of the Faculty No. 1 of Kharkiv National University of Internal Affairs, Ukraine.

${ }^{36}$ Doctor of Juridical Sciences, Professor, Head of the Department of Administrative Law, process and administrative activities Dnipropetrovsk State University of Internal Affairs, Ukraine.

${ }^{37}$ Candidate of Juridical Sciences, Associate Professor, Associate Professor of Department Labor and Economic Law of the Faculty No. 2, Kharkiv National University of Internal Affairs, Ukraine.
}

\begin{abstract}
Целью статьи является сформулировать определение понятия дисциплинарная ответственность работников полиции, выделить и исследовать особенности данного вового явления в системе права отдельных цели использовался комплекс общенаучных и специальных методов познания, в частности, герменевтический метод, логический метод схождения от простого к сложному, логикосемантический, логико-юридический, сравнительно-правовой метод. В статье исследованы особенности дисциплинарной ответственности работников полиции. Сделан вод о том, что дисциплинарную ответственность работников полиции следует понимать как институт объективного права и как элемент содержания права. Акцентировано внимание на том, что дисциплинарная ответственность работников полиции имеет ряд особенностей: 1) работники полиции относятся к отдельной категории лиц, которые, согласно действующему законодательству, являються субъектами специальной дисциплинарной ответственности; 2) содержание дисциплинарного правонарушения (проступка) работника полиции шире, чем у лиц, не состоящих на государственной службе; 3) число
\end{abstract}




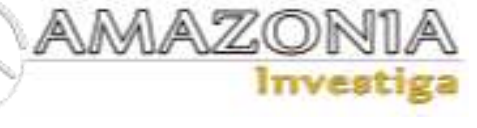

Key words: disciplinary responsibility, legal status, legality, police officer, responsibility. дисциплинарных взысканий, применяемых к работникам полиции шире, чем для работников, не состоящих на государственной службе; 4) порядок привлечения к дисциплинарной ответственности работников полиции Украины является специфическим; 5) работники Национальной полиции Украины привлекаются к дисциплинарной ответственности в случае совершения любого правонарушения административного, гражданского).

Ключевые слова: дисциплинарная ответственность, законность, ответственность, правовой статус, работник полиции.

\section{Introduction}

One of the priorities of a state that recognizes itself as the legal, democratic and social state is the protection of legitimate interests, freedoms and rights of man and citizen. In order to achieve this goal, the all state apparatus of the country have to function effectively.

Law enforcement agencies in general and structural units of the police, in particular, play one of the main roles in the implementation of the functions of a democratic, legal, social state. Therefore, one of the goals of the police of democratic European countries is to serve the people, protect their rights, freedoms and legitimate interests, ensure security and order, provide law enforcement services. The level of law and order in the state and society largely depends on the effectiveness of the tasks assigned to the police by the state.

A police officer as an official has state powers, As a citizen a police officer during service and in everyday life, must strictly adhere to official discipline, unquestioningly and accurately comply with the requirements of regulations. Achieving the goal of the police and the implementation of certain tasks of this law enforcement agency of the state depends on the responsible attitude of all police officers to the performance of their duties.

Legal attitudes to the proper implementation of the law by police officers can be formed through both incentives and coercive measures. At the same time, the system of measures aimed at forming an appropriate variant (type) of positive legally significant behavior in a police officer should be at the regulatory level. In our opinion, the clarity of regulations that regulate the grounds and procedure for the use of incentives and coercive measures lead to the strengthening of the rule of law and discipline in the police and in society.

Disciplinary liability of police officers is one of the main means of ensuring that police officers effectively perform their official duties and do not violate the rule of law, official discipline. The fact of existence at the legislative level of normative provisions on the possibility of applying to offenders appropriate negative measures of property, personal, moral, legal consciousness of a police officer, determines the option of his legally significant behavior. It is significant that disciplinary liability, on the one hand, influences the choice of lawful conduct by a police officer, and, on the other hand, disciplinary liability is a state reaction to a police officer's failure to perform or improper performance of his or her duties.

In view of the above in this scientific article, the authors set themselves the goal of defining the concept of disciplinary responsibility of police officers, to identify and explore the features of this legal phenomenon in the legal system of individual European states.

\section{Literature review}

Disciplinary responsibility is one of the guarantees of effective work of police officers of any European state. In this regard, disciplinary responsibility has been directly or indirectly studied in the works of a number of scientists, such as: Chapala (2010), Douglas (1950), Kovalenko (2008), Kuchenin (2011a, 2011b), Medvedev (2011), Nikiforov (1998), Podorozhnii (2014a, 2014b), Samoilov (2006), Sirokha, Felyk, Podorozhnii, Y. and Podorozhnii, A. (2020). However, the organizational nature affects the formation of the 
disciplinary responsibility of police officers, scholars have not studied enough yet.

\section{Methodology}

In order to define the concept of "disciplinary responsibility of police officers" and to identify and study the features of this legal phenomenon in the legal system of individual European countries, we used a number of general scientific and special scientific methods.

In the process of working on this scientific article, such general scientific methods as the hermeneutic method, the logical method of ascent from simple to complex were used.

The hermeneutic method was used in the analysis of certain provisions of regulations, in order to clarify the content of specific rules of law. The logical method of ascent from simple to complex was used to clarify the features of disciplinary liability of police officers through the study of its features in the national legislation of Ukraine and a number of European countries.

Among the special scientific methods used: logical-semantic, logical-legal and comparativelegal methods. Logical-semantic and logicallegal methods allowed to formulate the author's definitions of the concepts "disciplinary responsibility of police officers as an institution of objective law", "disciplinary responsibility of police officers an element of the content of legal relations". The comparative legal method was used in the analysis of the peculiarities of disciplinary liability of police officers of individual European countries.

\section{Resultados y discusión}

\section{Presentation of key resarch findings}

Probably the most common conception of discipline is in terms of punishment or responsibility. To the average person, the word "discipline" carries a connotation of arbitrary and severe enforcement of rules and regulations laid down by those in authority. This very narrow conception, which has very appropriately been called "negative discipline" (Douglas,1950, p. 85 ), involves force or external influence and is based on the theory that compliance is obtained by the use of punishment or fear of penalties (Douglas,1950, p. 85).

As for the police officers, the official discipline in the police bodies of foreign countries is the activity of their employees to comply with the requirements of laws and other regulatory legal acts, duties stipulated by the official position, defined by the job description and the individual contract. In addition, official discipline in the police bodies of foreign countries is compliance with the prohibitions and restrictions established for police officers related to the performance of their official duties, as well as compliance with moral and ethical standards of behavior (Kuchenin, 2011a, p. 143-147).

It should be noted separately that the violation of discipline by a police officer is the reason for bringing him to legal responsibility.

In this understanding, the concept of "discipline" is closely related to the concept of legal responsibility, namely this type of legal responsibility as disciplinary responsibility.

Disciplinary responsibility occupies a central, key place in the system of legally defined types of legal liability of employees of the National Police of Ukraine.

The main legal acts that regulate the disciplinary liability of employees of the National Police of Ukraine are: the Labor Code, the Law of Ukraine "On the Disciplinary Statute of Internal Affairs", the Law of Ukraine " About public service ", etc (Law № 322 VIII, 1971; Law № 3460-IV, 2006; Law № 889-VIII, 2015).

The system of legal norms that regulate the legal status of police officers in some foreign countries is formed, as a rule, by national laws "On the Police", decrees, ordinances of heads of state and heads of the executive branch. Also, this system includes regulatory legal acts of local selfgovernment bodies, which contain provisions on the legal status of certain categories of police personnel. These legal acts concretize the moral requirements for the work of police officers, also the requirements for their discipline, in addition to regulating certain elements of the legal status of police officers, such as duties, rights, responsibility, measures of special legal and social protection (Kuchenin, 2011a, p. 145).

An analysis of the provisions of the Labor Code of Ukraine shows that this codified act does not clearly define the concept of disciplinary liability. In the Labor Code, the legislator stipulates the obligation for employees to work honestly and conscientiously, timely and accurately comply with the instructions of the owner or his authorized body, adhere to labor and technological discipline, labor protection regulations, carefully treat the property of the 
owner with whom the employment contract (Law № 322 VIII, 1971).

According to the Art. 1 of the Disciplinary Statute of the National Police of Ukraine, service discipline is the police officers' observance of the Constitution and laws of Ukraine, international treaties, the consent of which is provided by the Verkhovna Rada of Ukraine, acts of the President of Ukraine and the Cabinet of Ministers of Ukraine, orders of the National Police of Ukraine, normative legal acts of the Ministry of Internal Affairs Ukraine, the oath of the police officer, orders of leaders (Law № 3460-IV, 2006).

A review of the legal literature suggests that legal scholars have repeatedly raised the issue of formulating the definition of "disciplinary responsibility" at the scientific level (Kuchenin, 2011b, p. 252; Kovalenko, 2008, p. 235; Kovalenko, 2009a, p. 131; Kovalenko, 2015, p. 235-243; Samoilov, 2006; Nikiforov, 1998).

In labor law E.Yu. Podorozhnii defines disciplinary liability as a special legal status that develops between the employer and the employee as a result of a violation of labor discipline by the employee, and the essence of which is the employer's right to apply such penalties to such employee. In addition, E.Yu. Podorozhnii defines disciplinary liability as the obligation of the employee to suffer for himself certain, due to the application of disciplinary sanctions, adverse consequences, the type and extent of which is determined by labor law (Podorozhnii, 2014a, p. 185).

There is an opinion that Discipline in the police is the strict and accurate execution by police in accordance with the procedure and rules established by the legislation of Ukraine, their duties, the exercise of their powers and compliance with job restrictions in the course of their official activities (Sirokha, Felyk, Podorozhnii Y., Podorozhnii A., 2020, p. 491).

V.V. Zhernakov, S.M. Prylypko, O.M. Yaroshenko under the disciplinary responsibility of employees suggest to understand the obligation of the employee to bear the punishment provided by the norms of the labor legislation, for illegal non-performance or improper performance of the labor duties (Zhernakov, Prylypko, Yaroshenko, 2012, p. 486).

According to P.D. Pilipenko disciplinary liability is the duty of the employee to bear responsibility for the violation of labor discipline before the employer and to bear the disciplinary sanctions provided by labor law (Pilipenko, 2007, p. 152).

K.V. Kovalenko defines disciplinary liability as the application to a guilty employee in the manner and under the conditions provided by labor legislation, disciplinary sanctions in the form of restrictions of a personal or organizational nature (Kovalenko, 2009b, p. 11).

In the pages of administrative and legal literature, disciplinary liability of ordinary and senior police officers of Ukraine is understood as a specific form of response by the state represented by its competent authorities. According to this specific form of response by the state, persons of the rank and file and chiefs of the police of Ukraine who have committed misdemeanors must be punished, which consists in the application of disciplinary sanctions by officials of the police of Ukraine in the manner prescribed by law. (Medvedev, 2011, p. 6); or as a special legal status of the subjects of disciplinary relations, which occurs when a guilty person commits a disciplinary offense (Chapala, 2010, p. 13-14).

Based on the above definitions and based on the general theoretical provisions of legal liability as a form of state coercion (Kalenichenko, 2017), we have grounds to define the disciplinary responsibility of police officers as provided by sanctions, provided for the possibility of state coercion, adverse consequences of which police officer suffers for a disciplinary offense committed by him, in the manner prescribed by law (disciplinary responsibility of police officers as an institution of objective law).

Disciplinary responsibility of police officers as an element of the content of legal relations is a duty of a police officer provided by sanctions of legal norms to be deprived of disciplinary character in legal relations arising from the fact of disciplinary offense.

In our opinion, it is necessary to distinguish between general and special disciplinary responsibility of employees of the National Police of Ukraine.

At the same time, we consider it appropriate to immediately note that the procedure, conditions, grounds for the application of general disciplinary responsibility of employees of the National Police of Ukraine are regulated by labor legislation. The procedure, conditions, grounds for the application of special 
disciplinary responsibility of employees of the National Police of Ukraine are regulated by regulations governing police activities, such as administrative law, the Law of Ukraine "On Disciplinary Statute of Internal Affairs of Ukraine". (Law № 3460-IV, 2006).

Regardless of the type of disciplinary liability, the only basis for imposing a disciplinary sanction on an employee of the National Police of Ukraine is the commission of a disciplinary (labor) offense (misdemeanor).

Labor legislation does not define labor misconduct (Law № 322 VIII, 1971). Instead, Article 2 of the Law of Ukraine "On the Disciplinary Statute of the Internal Affairs Bodies of Ukraine" defines a disciplinary misconduct as non-performance or improper performance by a person of the rank or file service discipline (Law № 3460-IV, 2006).

In the national legislation of a number of foreign countries, a disciplinary violation is defined at length. So, in Germany it is "any violation committed by a police officer in (or) in connection with the exercise of his duties". In the UK, Italy, Spain, France, the concept of a disciplinary offense is interpreted in a similar way (Kuchenin, 2011a), which means the authority of an instance with the necessary disciplinary power to decide independently whether a particular fact is a violation of official discipline or not. At the same time, the decisive importance of the principle of the rule of law in the actions of police officers is emphasized: "No criminal and disciplinary sanctions can be applied to a police officer who refuses to obey an unlawful order” (Resolution № 690, 1979; Kuchenin, 2011a)

Employees of the National Police of Ukraine are brought to disciplinary responsibility, first, for committing an administrative offense under the provisions of Art. 15 of the Code of Ukraine on Administrative Offenses; secondly, for violating the provisions of Art. 7 of the Law of Ukraine "On the Disciplinary Statute of the bodies of internal affairs of Ukraine", which consolidate the responsibilities of privates and officers (Law № 8073-X, 1984; Law № 3460-IV, 2006).

The provisions of Article 147 of the Labor Code stipulate penalties for violations of labor discipline. Therefore, for violation of labor discipline, an employee may be subject to only one of the following sanctions: reprimand or dismissal (Law № 322 VIII, 1971).
Note that the provisions of Part 2 of Art. 147 of the Labor Code indicate that the legislation, statutes and regulations on discipline may provide for certain categories of employees and other disciplinary sanctions (Law № 322 VIII, 1971).

Employees of the National Police of Ukraine belong to certain categories of employees. According to Article 12 of the Law of Ukraine "On the Disciplinary Statute of Internal Affairs of Ukraine", the following types of disciplinary sanctions may be applied to them: oral reprimand, reprimand, severe reprimand, warning of incomplete incompatibility, dismissal, demotion by a special rank, dismissal from internal affairs bodies (Law № 3460-IV, 2006).

In the national legislation of a number of foreign countries, penalties such as reprimand, demotion, dismissal from service are typical for police officers. In foreign countries, disciplinary measures such as a reduction in the official salary for a certain period (Germany, France, Italy, Armenia) or disciplinary arrest can also be applied against police officers (Law of the Republic of Armenia № 3P-401, 2002).

Section IV of the Law of Ukraine "On the Disciplinary Statute of the Bodies of Internal Affairs of Ukraine" regulates the procedure, deadlines for imposing disciplinary sanctions, as well as the procedure for execution and removal of disciplinary sanctions of employees of the National Police of Ukraine. Although at the level of labor legislation (Labor Code) the procedure, the timing of disciplinary action is also regulated.

In most developed countries, disciplinary sanctions are imposed on police officers after the mandatory consideration of the case by a disciplinary council - a commission acting on an equal footing. In Belgium, Italy, France, Great Britain, Canada, the United States and in other countries, a police officer can present his objections, refer to witnesses, use the help of a defense lawyer (Kuchenin, 2011a, p. 146).

It is noteworthy that disciplinary sanctions are applied to employees of the National Police of Ukraine when bringing them to administrative, material and criminal responsibility. That is, disciplinary liability, in the case of a police officer committing an administrative, criminal offense, is a mandatory additional type of responsibility. 


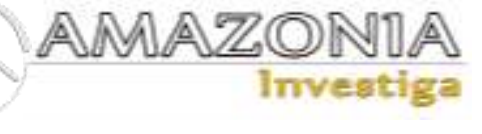

On the one hand, this state of affairs contradicts the principle of fairness of legal responsibility (Podorozhnii, 2014b, p. 78). However, on the other hand, the only reason for bringing a person to disciplinary responsibility is a disciplinary misdemeanor in the form of non-performance or improper performance of official discipline by an employee of the National Police of Ukraine (compliance with police regulations) (Law № 3460-IV, 2006). In the case of a police officer committing any offense, the rules of regulations are violated, and, consequently, a disciplinary offense is committed, respectively, there are grounds for imposing a disciplinary sanction.

\section{Conclusions}

Based on the analysis of the disciplinary responsibility of police officers, we consider it appropriate to draw the following conclusions.

The disciplinary responsibility of police officers should be understood as an institution of objective law and as an element of the content of legal relations.

Disciplinary liability of police officers as an institution of objective law - provided by sanctions of law, provided with the possibility of state coercion, adverse consequences that a police officer suffers for a disciplinary offense committed by him, in the manner prescribed by law.

Disciplinary liability of police officers as an element of the content of legal relations is a duty of a police officer provided by sanctions of legal norms to be deprived of disciplinary character in legal relations arising from the fact of disciplinary offense.

The disciplinary responsibility of police officers has a number of features:

1) Police officers belong to a separate category of persons who, according to the current legislation, are subjects of special disciplinary responsibility; the content of a disciplinary offense (misconduct) of a police officer is broader than that of persons who are not in the public service. 2) Employees of the National Police of Ukraine, unlike citizens who do not serve in law enforcement agencies, are brought to disciplinary responsibility not only for violation of labor legislation, but for violation of the disciplinary Statute.

3) The number of disciplinary sanctions applied to police officers is wider than for employees who are not in the public service.
4) The procedure for bringing to disciplinary responsibility of police officers of Ukraine is specific.

5) Employees of the National Police of Ukraine are brought to disciplinary responsibility in case of committing any offense (criminal, administrative, civil).

\section{References}

Chapala, O.Yu. (2010) Administrative and legal regulation of service in the bodies of internal affairs of Ukraine (abstract of the dissertation for the degree of candidate of legal sciences) "Administrative law and process; financial rights; information law". University of Internal Affairs affairs, Kharkiv. 19 p.

Douglas, G. (1950) Gourley Police discipline. Journal of Criminal Law and Criminology, 41(1), pp. 85.

Kalenichenko, L.I., (2017) Legal responsibility as a form of state and legal coercion: a monograph. Kharkiv: NTMT Publishing House, $348 \mathrm{p}$.

Kovalenko, K.V. (2008). General and special disciplinary liability. Law Forum, № 2, 231-236. http://www.nbuv.gov.ua/e-journals/FP/2008-

2/08kkvsdv.pdf

Kovalenko, K.V. (2009a) Disciplinary liability of police officers. Actual problems of the state and business, 46, 130-136. http://www.apdp.in.ua/v46/21.pdf

Kovalenko, K.V. (2009b). Legal regulation of disciplinary responsibility of employees of lawenforcement bodies (the dissertation author's abstract on competition of a scientific degree of the candidate of legal sciences) East Ukrainian nat. Univ. V. Dahl, Lugansk, 23 p. http://disser.com.ua/pravove-rehuljuvannjadystsyplinarnoyi-vidpovidalnosti-pratsivnykivorhaniv.html

Kovalenko, K.V. (2015). The difference between disciplinary liability and other types of legal liability. Bulletin of Kharkiv National University of Internal Affairs, № 2(69), 235-243. http://dspace.univd.edu.ua/xmlui/handle/123456 789/256

Kuchenin, E. (2011a) Institute of office discipline in national police systems of the foreign states. Bulletin of the Moscow University of the Ministry of Internal Affairs of Russia, 2, 143-147.

https://cyberleninka.ru/article/n/institutsluzhebnoy-distsipliny-v-natsionalnyhpolitseyskih-sistemah-zarubezhnyhgosudarstv/viewer

Kuchenin, E.S. (2011b). Characteristic features of the disciplinary responsibility of employees of the Internal Affairs Bodies. Bulletin of the 
Moscow University of the Ministry of Internal Affairs of Russia, № 8, 249-252. https://cyberleninka.ru/article/n/harakternyecherty-distsiplinarnoy-otvetstvennostisotrudnikov-ovd/viewer

Law № 322 VIII Labor Code of Ukraine. Verkhovna Rada of Ukraine, december 10, 1971. http://zakon3.rada.gov.ua/laws/show/322-08 Law № 3460-IV. On the Disciplinary Statute of the Bodies of Internal Affairs of Ukraine. February 22, 2006. Available online http://zakon3.rada.gov.ua/laws/show/3460-15 Law № 8073-X. Code of Ukraine on Administrative Offenses. December 7, 1984. Available online

https://zakon.rada.gov.ua/laws/show/80731-

10/stru\#Stru

Law № 889-VIII. About public service. December 10, 2015. Available online https://zakon.rada.gov.ua/laws/show/889-

19\#Text

Law of the Republic of Armenia № 3P-401 On police service. July 30, 2002. http://www.parliament.am/legislation.php?sel=s how \&ID=1640\&lang=rus

Medvedev, A.M. (2011). Disciplinary responsibility of privates and chiefs of internal affairs bodies (dissertation author's abstract for the degree of Candidate of Law) Nat. acad. interno Asuntos, Kyiv, 22 p. http://disser.com.ua/dystsyplinarna-

vidpovidalnist-osib-rjadovoho-i-

nachalnytskoho-skladu-orhaniv.html

Nikiforov, A.V. (1998). Disciplinary responsibility of employees of law-enforcement bodies (dissertation of the candidate of legal sciences) Odessa Law Institute, Omsk, 202 p. https://www.dissercat.com/content/distsiplinarn aya-otvetstvennost-sotrudnikov-organovvnutrennikh-del
Pilipenko, P.D. (Ed.) (2007) Labor law of Ukraine: a textbook. Kyiv: Istina. (208 p.). https://shron1.chtyvo.org.ua/Pylypenko_PD/Tru dove_pravo_Ukrainy.pdf?PHPSESSID=7rns9ak obukj9s12vn3tcouea2

Podorozhnii, Y. (2014a) The concept of disciplinary responsibility and the mechanism of its functioning. Scientific Bulletin of the Academy of Municipal Administration: Law Series, 1, 183-188. http://nbuv.gov.ua/UJRN/Nvamu_pr_2014_1_3 6

Podorozhnii, Y. (2014b). Features of retrospective legal liability of law enforcement officers for violation of labor law. Scientific Bulletin of Uzhhorod National University, 29(2.3), 75-79. http://nbuv.gov.ua/UJRN/nvuzhpr_2014_29\%2 $82.3 \% 29 \_18$

Resolution № 690 of the Parliamentary Assembly of the Council of Europe. Declaration on the Police, May 8, 1979. Available online. https://zakon.rada.gov.ua/laws/card/994_803

Samoilov, V.G. (2006). Disciplinary responsibility in labor law: general and special. (dissertation of the candidate of legal sciences) Moscow State Law Academy, Moscow. 177 c. Sirokha, D., Felyk, V., Podorozhnii, Y., Podorozhnii, A. (2020) Basic aspects of the compliance with discipline and legitimacy within the official activities of police. Amozonia Investiga, $\quad 9(25), \quad 487-492$. https://amazoniainvestiga.info/index.php/amazo nia/article/view/1098

Zhernakov V.V., Prylypko S.M., Yaroshenko O.M. and others; for order. V.V. Zhernakov (2012) Labor law: a textbook. Kharkiv: Pravo, (496 p.). https://www.twirpx.com/file/1158697/ 